\title{
Helping Teachers Develop Positive Dispositions about Technology-based Learning: What a Brief Global Learning Project Revealed
}

\author{
Carol A. Smith \\ West Chester University of Pennsylvania \\ Cynthia A. Moyer \\ J. Mason Tomlin School of Mantua, New Jersey \\ Heather R. Schugar \\ West Chester University of Pennsylvania
}

\begin{abstract}
Research indicates that teachers' dispositions significantly influence their integration of computer technology into classroom instruction. This article reports findings from a mixedmethods study that examined shifts in teachers' dispositions about learning that occurs through information and communication technologies (ICT'S). Graduate students and remote professionals engaged in a one-semester learning project that included synchronous and asynchronous computer-mediated discussions of course content. The study sought to determine whether or not this exposure to ICT-based learning might be accompanied by a positive or negative affective shift, and to identify the salient features of such a shift. Quantitative analysis of responses on questionnaires administered early and late in the semester revealed a statistically significant positive shift in participants' beliefs and dispositions regarding ICT-based learning. Qualitative analysis of the questionnaire responses and participants' digital discussions identified two salient features of that positive shift in that participants recognized the potential of ICT-based learning to 1) motivate and engage learners, and 2) facilitate the construction and sharing of new knowledge and understanding. This paper describes the study and considers the implications for teacher preparation and professional development.
\end{abstract}

Keywords: teacher dispositions, teacher preparation, global learning, ICT's

\section{Introduction and Literature Review}

Important knowledge about digital literacy for the $21^{\text {st }}$ Century continues to emerge. Researchers (Cervetti, Damico, \& Pearson, 2006; Guthrie, 2004; Leu, Kinzer, Coiro, \& Cammack, 2004; O’Brien \& Scharber, 2008) have identified practices, skills, strategies, and dispositions that are required for digital reading, writing, collaborating, and learning. Additionally, researchers propose new teaching and learning models (Armstrong \& Warlick, 2004; Leu, 2001; Richardson, 2010) that facilitate the development of those new 
literacies and enable students to participate in global learning experiences mediated by ICT's (information and communication technologies). However, teachers' classroom application of this knowledge remains limited (Tan \& Guo, 2009/2010; Williams, 2011b). Karchmer's (2001) landmark study revealed the need for more effective teacher preparation in the realm of computer-based learning, but more recent studies (Marsh, 2008; Rother, 2004) suggest little progress has been made. Kay's (2006) review of the literature suggests that pre-service education programs have not successfully prepared new teachers to integrate technology effectively. Except for keyboarding, technology skills rarely play central roles in school-based learning, and traditional print literacies continue to dominate (Tierney, 2009). Williams (2011b) discusses two unfortunate consequences: 1) teachers fail to recognize that what they refer to as "e-learning" is quite simply the way many learners gather information outside of school, and 2) disaffected students are dropping out of school in record numbers. The challenge persists for teacher educators and professional developers to identify strategies and pedagogies that will better prepare teachers to integrate computer technology into classroom instruction and engage students in ICT-based learning.

Researchers and theorists in the realm of new literacies (Cervetti, Damico, \& Pearson, 2006; Leu, Kinzer, Coiro, \& Cammack, 2004; O'Brien \& Scharber, 2008) maintain that ICT's are central to literacy within a global community in the information age, that ICT's require new literacies, and that learning within those new literacies is often socially constructed. Among the new literacies that ICT's require is the ability to engage in threaded discussions and interactive chats in order to manage information (Guthrie, 2004) and share intellectual capital to solve important problems (Leu, Kinzer, Coiro, \& Cammack, 2004). To help students develop these new literacies and acquire the requisite skills, teachers are encouraged (Armstrong \& Warlick, 2004; Leu, 2001; Richardson, 2010; Williams, 2011a) to replace traditional learning models with new models whereby students use the Internet and other ICT's to collaboratively explore and solve problems. In these models, geographically remote learners locate, read, write, and synthesize digital texts to socially construct and communicate new knowledge, thereby deepening their understanding of the problems under consideration. Thus, research provides important information about what $21^{\text {st }}$ Century teachers should teach and how they might best teach it. However, additional research reveals that teacher-knowledge alone is insufficient. Other important factors, including teacher dispositions, impact the likelihood that teachers will apply what they know about computer-mediated learning in their classrooms.

Teachers' effective integration of computer technology reflects and correlates with their personal beliefs and dispositions regarding the potential benefits (Cervetti, Damico, \& Pearson, 2006; Ertmer, 2005; MacArthur \& Malouf, 1991; Vannatta \& Fordham, 2004). Teachers who demonstrate strong motivation to use computers for their own personal and professional purposes believe that computer integration will support their students' learning as well (MacArthur \& Malouf, 1991). After reviewing related literature, Cervetti, Damico, and Pearson (2006) argued that teacher educators might facilitate much-needed educational reform if they could help teachers recognize technology as helpful for their own personal development. The authors further argued that teachers might acquire that important disposition if they had opportunities to learn not just about technology, but through technology, in courses that focused on other content (e.g., not in technology courses).

In summary, research has yielded much information about ICT-based learning, models that will facilitate such learning, and disposi- 
tions that correlate with teachers' instructional integration of computer technology. This information challenges classroom teachers to adopt ICT-based global learning models that will develop students' digital literacy skills and practices. It challenges teacher educators and professional developers to engage teachers and teacher candidates in ICT-based global learning of course content, thereby fostering the development of positive dispositions that correlate with classroom integration of computerbased learning.

\section{Purpose of the Study}

While the challenge for teacher preparation and professional development is clear, a number of questions require investigation. Research has identified a positive correlation between teachers' dispositions and their classroom integration of computer-based learning; however, the suggestion that teachers will develop positive dispositions as they engage in ICT-based learning of course content warrants testing and exploration. Teacher educators and professional developers need to know whether or not that suggestion is valid, how extensive the ICT-based learning experience must be, and how they might recognize the positive dispositions they seek to effect. The goal of this study was to examine teachers' responses to a brief and limited experience with ICT-based global learning across just one semester. The study sought to determine whether or not teachers' dispositions would shift - and if so, in which direction - as they engaged in learning through technology for their own professional development. It also sought to identify the salient features of any shift that might occur.

The lead researcher, also a university instructor, designed a global learning experience and integrated it into a traditional, oncampus, one-semester graduate course that focused on problems in literacy development. At designated times across the semester, stu- dents engaged in computer-mediated discussion rather than attending class on campus; hence, the course model was hybridized. During each of those distance-learning sessions, class members engaged in computer-mediated discussion of problems teachers face in working with struggling readers. They also shared ideas about effective pedagogical strategies and approaches. Joining in those discussions were practicing teachers not enrolled in the course - but invited by the instructor - each of whom brought considerable knowledge and expertise in that realm. Asynchronous discussions took place on digital message boards; synchronous discussions took place in live chat rooms. From the participants' posted messages and live chat transcripts, the instructor culled talking points for later consideration during traditional on-campus class meetings. Thus, the participants engaged in global learning to explore and solve course-related problems through ICT-based communications with each other and remote practitioners. Throughout the semester, the instructor gathered data for quantitative and qualitative analysis to answer two research questions:

1. Will graduate students and practicing teachers who participate in 5 global learning sessions across one semester demonstrate a shift in disposition and belief regarding the value of ICT-based learning?

2. What might be the salient features of such a dispositional shift?

\section{Methodology}

\subsection{Participants}

Twenty female teachers of grades ranging from kindergarten through high school participated in the study. Eighteen were students enrolled in a graduate course in reading at a university in the Mid-Atlantic region of the United States and two were language arts teachers from a neighboring state. The two teachers from a nearby state participated as real-world experts 
working with struggling readers. In return for their participation, the remote teachers received credit for continuing education hours required by their state department of education, and the graduate students received participation points toward their final grade in the course. The instructor introduced the global learning sessions merely as a required component of the course; not until the final class session of the semester did the instructor explain the project and gain participants' informed consent for analysis and sharing of the collected data.

\subsection{Research Design}

A mixed-methods design facilitated quantitative and qualitative analysis of data gathered first through questionnaires and later through discourse analysis. Statistical analysis of responses on early- and late-semester questionnaires enabled the researchers to identify the presence and direction of participants' dispositional shift. Discourse analysis of participants' responses to open-ended questions, as well as printed transcripts from digital discussions, yielded deeper understanding of that shift by identifying salient features.

\subsection{Procedures and Data Collection}

Participants constituted a global learning community that engaged in a series of five computer-mediated discussion sessions. During sessions 1 through 4, discussion focused on one or more problems in literacy development, which was the topic of this particular graduate course. During the $5^{\text {th }}$ and final session, participants posted reflective statements sharing their thoughts about the ICT-based global learning experience they had just completed. Sessions 1,2 , and 5 were asynchronous in that participants posted messages on an electronic message board, read messages posted by other participants, selected posts of interest to them, and posted responses to extend the discourse. Each of these asynchronous discussion sessions spanned one week. Postings remained available on the board for later analysis. Sessions 3 and 4 were synchronous in that participants logged into a Live Classroom ${ }^{\circledR}$ site, moved into smaller breakout rooms, and conversed electronically for approximately an hour per session. After each of the five ICT-based sessions, the instructor read through the digital messages or transcripts to identify remarks, topics, or issues that warranted follow-up discussion during the next on-campus class session. Table 1 summarizes the 5 ICT-based sessions.

In addition to participating in the five ICTbased global learning sessions, all participants completed questionnaires. A modified version of Keuchler's (2008) Blackboard Technology Questionnaire, administered early and late in the semester, yielded both quantitative and qualitative data. It included sixteen items, eleven of which pertained to this study and five of which pertained to course content. Of the study-related items, seven requested information used to construct an initial profile of the participants, two assessed participants' beliefs and dispositions related to ICT-based global learning, and two invited participants to comment freely upon ICT-based learning for themselves and for their students. Items used for quantitative analysis were on a 4-point scale; respondents chose one of 4 numeric response options. The late-semester questionnaire included additional items: one invited participants to comment freely upon this particular global learning experience, and the other asked them to numerically assess its benefit to them as learners. To encourage candid responses, the instructor did not collect the late-semester questionnaires. Rather, a class member collected and held them until final course grades had been officially posted; she then mailed the completed questionnaires to the instructor. 
Table 1. Summary of ICT-based Global Learning Sessions

\begin{tabular}{|c|c|c|c|}
\hline Session & Discussion format & Focus/topic & Data generated \\
\hline 1 & Asynchronous & $\begin{array}{l}\text { Topics gleaned from } \\
\text { participants' comments on } \\
\text { early-semester questionnaire }\end{array}$ & $\begin{array}{l}\text { Posted messages \& } \\
\text { replies saved on electronic } \\
\text { discussion board }\end{array}$ \\
\hline 2 & Asynchronous & $\begin{array}{l}\text { Motivating \& supporting } \\
\text { struggling older readers; } \\
\text { helping them acquire literacies; } \\
\text { blending print \& digital } \\
\text { literacies }\end{array}$ & $\begin{array}{l}\text { Posted messages \& } \\
\text { replies saved on electronic } \\
\text { discussion board and printed } \\
\text { for analysis }\end{array}$ \\
\hline 3 & Synchronous & $\begin{array}{l}\text { How general educators and } \\
\text { special educators communicate } \\
\text { and collaborate to facilitate } \\
\text { literacy development for } \\
\text { struggling readers }\end{array}$ & $\begin{array}{l}\text { None (Attempts to archive } \\
\text { data failed) }\end{array}$ \\
\hline 4 & Synchronous & $\begin{array}{l}\text { Successful \& unsuccessful } \\
\text { attempts to engage and support } \\
\text { struggling readers }\end{array}$ & $\begin{array}{l}\text { Remarks saved as Word } \\
\text { documents and e-mailed to } \\
\text { instructor for analysis }\end{array}$ \\
\hline 5 & Asynchronous & $\begin{array}{l}\text { Personal reflections upon } \\
\text { session } 4\end{array}$ & $\begin{array}{l}\text { Posted messages \& } \\
\text { replies saved on electronic } \\
\text { discussion board and printed } \\
\text { for analysis }\end{array}$ \\
\hline
\end{tabular}

\section{Results}

\subsection{Initial Profile of Participants}

Analysis of response frequencies for six items on the early-semester questionnaire revealed that participants had very limited prior experience with ICT-based learning: $25 \%$ reported no ICT-based learning; 30\% reported ICT-based learning in one previous course; $35 \%$ reported ICT-based learning in two or three courses; and 10\% reported ICT-based learning in more than three courses. Furthermore, when previous courses did include ICT-based learning, it typically happened only once in the semester; only $20 \%$ of respondents reported participating in ICT-based learning more than one time per semester in any previous course. In addition to limited experience as ICT-based learners, participants also reported limited integration of ICT-based learning into their classroom teaching; 25\% reported having previously engaged their students in ICT-based learning more than once per school year; the vast majority reported no past engagement at all.

\subsection{Quantitative Analysis to Identify Disposi- tional Shift across the Semester}

Quantitative analysis of 2 questionnaire item responses revealed statistically significant positive shifts in disposition regarding ICTbased learning across the semester. Responding to those items, participants selected one of four numeric response options, with option \#1 reflecting the strongest negative disposition, and option \#4 reflecting the strongest positive disposition. Table 2 shows these two questionnaire items and response options. 
Table 2. Questionnaire Items Used to Measure Dispositional Shift across the Semester

\begin{tabular}{|c|c|c|c|c|}
\hline Item & $\begin{array}{c}\text { Response option } \\
\# 1\end{array}$ & $\begin{array}{c}\text { Response option } \\
\# 2\end{array}$ & $\begin{array}{l}\text { Response option } \\
\text { \#3 }\end{array}$ & $\begin{array}{l}\text { Response option } \\
\text { \#4 }\end{array}$ \\
\hline $\begin{array}{l}\text { Part I, item \#5 } \\
\text { Which of the } \\
\text { following } \\
\text { comes closest } \\
\text { to your view } \\
\text { on ICT-based } \\
\text { global learning } \\
\text { for your own } \\
\text { learning? }\end{array}$ & $\begin{array}{l}\text { It does not help; } \\
\text { it just makes } \\
\text { things more } \\
\text { complicated. }\end{array}$ & $\begin{array}{l}\text { It may support } \\
\text { learning, but } \\
\text { I have not } \\
\text { yet found an } \\
\text { instructor using } \\
\text { it in ways that } \\
\text { helped me learn } \\
\text { the material. }\end{array}$ & $\begin{array}{l}\text { It is useful, but } \\
\text { I need better } \\
\text { technical skills } \\
\text { to take full } \\
\text { advantage. }\end{array}$ & $\begin{array}{l}\text { It makes learning } \\
\text { more fun, more } \\
\text { interesting, and/ } \\
\text { or more efficient. }\end{array}$ \\
\hline $\begin{array}{l}\text { Part 2, item \#3 } \\
\text { How do you } \\
\text { feel about ICT- } \\
\text { based global } \\
\text { learning? }\end{array}$ & $\begin{array}{l}\text { I hate it and } \\
\text { avoid it as best I } \\
\text { can. }\end{array}$ & $\begin{array}{l}\text { I find it } \\
\text { intimidating, but } \\
\text { I wish I knew } \\
\text { more. }\end{array}$ & $\begin{array}{l}\text { I find it useful, } \\
\text { but I don't love } \\
\text { it. }\end{array}$ & I just love it. \\
\hline
\end{tabular}

To score participants' responses, option \#1 was awarded a score of 1 , option \#2 a score of 2, option \#3 a score of 3 , and option \#4 a score of 4 . For each of the two items, paired-samples t-tests compared the early- and late-semester mean scores for participants' responses. The comparisons revealed statistically significant differences between early- and late-semester average scores on item \#5 $(p=.024)$ and item $\# 3(p=.001)$ (see Table 3$)$.
That positive shift in participants' dispositions was further examined by comparing the response frequencies for those two items on the early- and late-semester questionnaires. For item \#5, no participant chose the strongest negative response on either the early- or late-semester questionnaire. The number of somewhat negative responses decreased by 7 , the number of somewhat positive responses increased by 2 , and the number of strong positive responses increased by 5 (see Figure 1).

Table 3. Paired-samples t-tests for Questionnaire Items \#5 and \#3

\begin{tabular}{|c|c|c|c|c|c|c|}
\hline \multirow{2}{*}{ Questionnaire item } & \multicolumn{2}{|c|}{ Early-semester } & \multicolumn{2}{|c|}{ Late-semester } & \multirow[b]{2}{*}{$\mathrm{T}$} & \multirow{2}{*}{$\begin{array}{c}\text { Sig. } \\
\text { (2-tailed) }\end{array}$} \\
\hline & $\mathrm{M}$ & $\mathrm{SD}$ & $\mathrm{M}$ & SD & & \\
\hline Part 1 , item \#5 & 2.79 & .85 & 3.42 & .69 & -2.47 & $.024^{*}$ \\
\hline Part 2, item \#3 & 2.40 & .68 & 3.12 & .59 & -3.94 & $.001^{* *}$ \\
\hline
\end{tabular}




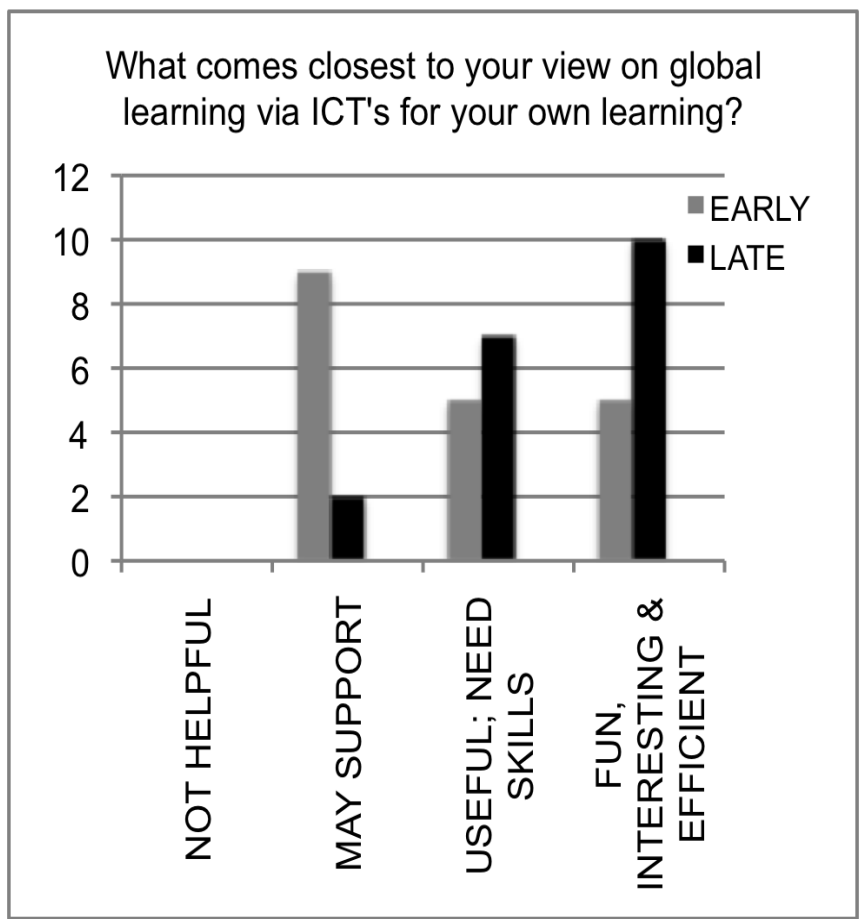

Figure 1. Comparison of early and late response option frequencies for Part 1, item \#5

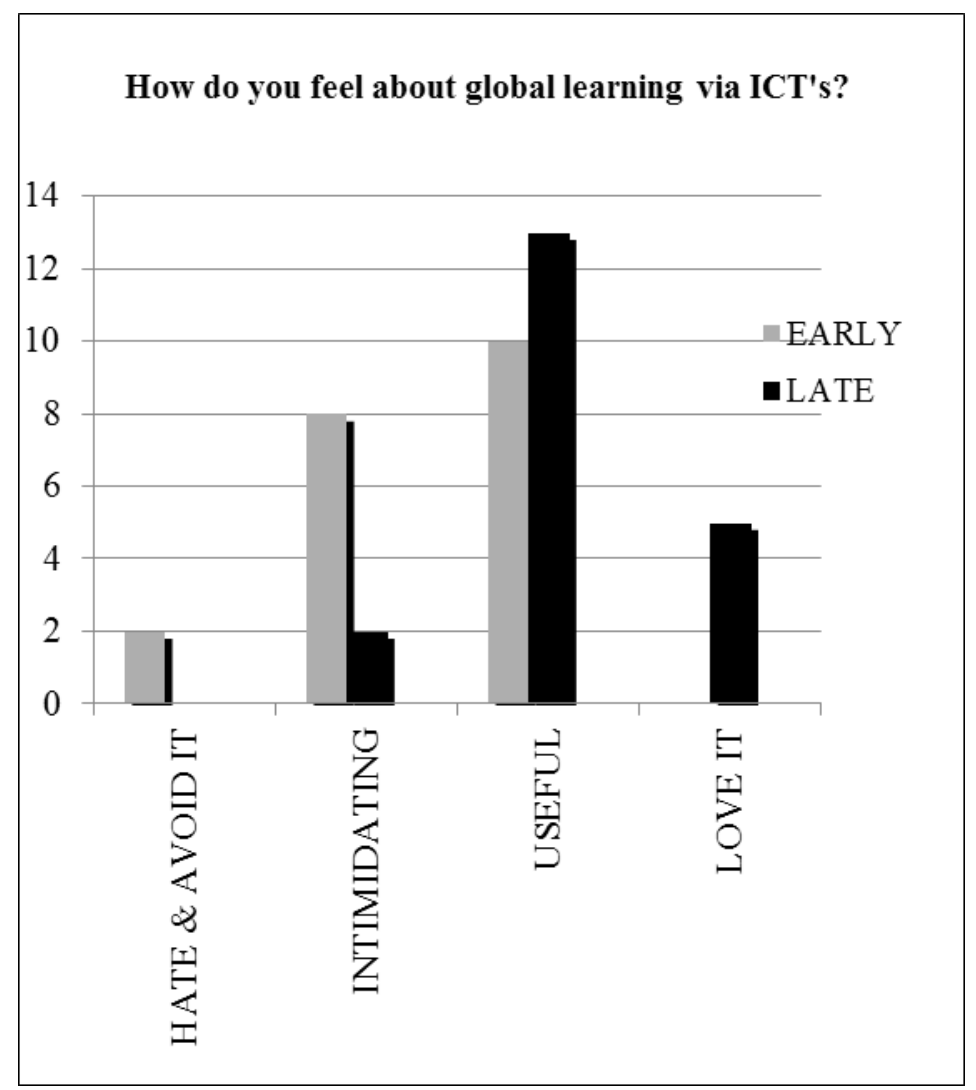

Figure 2. Comparison of early and late response option frequencies for Part 2, item \#3 
For Part 2, item \#3, two participants selected the strongest negative response on the early-semester questionnaire, but no participant selected it on the later questionnaire. The number of somewhat negative responses decreased by six, the number of somewhat positive responses increased by three, and the number of strong positive responses increased by five (see Figure 2).
An extra item appearing only on the latesemester questionnaire yielded additional quantitative data by asking participants to numerically assess the benefit of this particular global learning experience. No participant selected the strongest negative response statement. Two participants selected the somewhat negative response option, one selected the somewhat positive response option, and seventeen selected the strongest positive response option (see Table 4).

Table 4. Response Frequencies for Late-semester Evaluation of Global Learning Experience Questionnaire item: Which statement most closely describes your feelings about your global learning experience in this course?

\begin{tabular}{|c|c|}
\hline Response option & $\begin{array}{l}\text { Number (percentage) of } \\
\text { participants selecting this option }\end{array}$ \\
\hline $\begin{array}{l}\# 1 \text { - I have not benefited and would prefer not to } \\
\text { participate in global learning again }\end{array}$ & 0 \\
\hline $\begin{array}{l}\# 2 \text { - I have not benefited but would like to try global } \\
\text { learning again. }\end{array}$ & $2(10 \%)$ \\
\hline $\begin{array}{l}\text { \#3 - I have benefited but would prefer not to participate in } \\
\text { global learning again. }\end{array}$ & $1(5 \%)$ \\
\hline $\begin{array}{l}\text { \#4 - I have benefited and would like to participate in } \\
\text { global learning again. }\end{array}$ & $17(85 \%)$ \\
\hline
\end{tabular}

In summary, quantitative analysis of data from early- and late-semester questionnaires revealed statistically significant positive shifts in participants' dispositions regarding ICTbased global learning, and a predominantly positive response to this particular global learning experience.

\subsection{Qualitative Analysis to Identify Salient Features of the Dispositional Shift}

Addressing the second research question, qualitative analysis of questionnaire item responses and digital discussion transcripts identified salient features of the positive shift. Discourse analysis enables researchers to describe speakers' and/or writers' beliefs and feelings (Florio-Ruane \& Morrell, 2004; Goldman \& Wiley, 2004); therefore, two of the authors analyzed participants' constructed responses to open-ended items on the questionnaires and the printed transcripts from three of the ICTbased discussions. The researchers used a discourse analysis coding system developed a priori (Florio-Ruane \& Morrell, 2004), looking for statements reflecting participants' beliefs or dispositions about ICT-based learning. During an initial training session, the lead researcher explained and demonstrated the procedure by reading a few of the participants' constructed texts and highlighting examples. The two re- 
searchers then coded a few transcripts independently and compared their work to check for agreement. Because their separate coding showed complete agreement and exact correlation, the researchers agreed to complete the coding independently and meet later to compare highlighted statements that reflected participants' beliefs and dispositions about ICTbased learning. Following is an explanation of the researchers' procedures.

The first task was to find specific examples of dispositional shift. To do so, the researchers compared each individual participant's earlyand late-semester responses to open-ended items on the questionnaires, looking for cases in which the late-semester response differed notably from the early-semester response. That comparison of each participant's early and late responses reflected only positive shift; no case of negative shift was identified. When cases of notable difference were identified, the researchers looked for words or phrases that would provide insight into the respondent's thoughts or feelings. From that discourse analysis emerged two salient features of positive dispositional shift in that participants recognized the potential of ICT-based learning to a) motivate and engage learners and b) facilitate the construction and sharing of new knowledge and understanding. Representative comparisons of early- and late-semester responses are presented in Table 5.

Table 5. Representative Comparisons of Early- and Late-semester Responses to Open-ended Items

Questionnaire item: Enter any additional comments you may have about your own global learning through ICT's

Early-semester response

No response

No response

I have only experienced global learning in one other class.

No response
Late-semester response

I highly enjoyed the exposure this semester and hope to learn more.

I think it is an interesting new way of learning.

I felt the online chats with fellow teachers were very beneficial to my teaching. New strategies were shared.

Before this class I was unfamiliar with them. However I am very glad that I was exposed to the live classrooms and plan to use it [sic] in my own room.

Questionnaire item: Enter any additional comments you may have about global learning through ICT's for your students.

This would not be appropriate for my students without one-on-one support and willingness of parents.

No response

No response

Not in plans, but could change
I would love to do it with students who would be able to have reciprocal conversations.

A great way to motivate students

I feel it will be extremely engaging.

Can't wait to use it this year 
The researchers next confirmed those two salient features through similar discourse analysis of additional data sources by using responses to an open-ended item included only on the late-semester questionnaire, and printed transcripts of participants' digital discussions in the global learning sessions. That round of discourse analysis showed that, indeed, the participants had been motivated and engaged during the ICT-based learning sessions, their collab- orative construction of knowledge and understanding about course content had been facilitated, and they were metacognitively aware of both the engagement and the construction of knowledge. To illustrate those phenomena, Table 6 presents an excerpt from the synchronous live discussion that took place during session 4, and Table 7 presents some final reflections posted on the discussion board in session 5 .

Table 6. Discussion Excerpt Reflecting Engagement and Social Construction of Knowledge ICT-based session 4 - Synchronous chat about how to support struggling readers

AM My grade partner and I found this idea. You have children cut out a picture from a magazine. They glue it to another paper then continue the picture by adding more details. Then they can write a story about it.

EC I love that idea.

JM I love that idea, $A$.

AM For example, if I cut out a picture of someone sitting on the couch I might then add the rest of the room by drawing it on the paper, then I would write a sentence/story to tell what is happening or going to happen.

JL That's a great idea.

EC You could also do that activity with partners and have them build off one another's sentences.

$\mathrm{JM} \quad$ I'm going to use this strategy to motivate my struggling writers. This may also help the students to write about different ideas.

$\mathrm{JL} \quad$ I'm going to try it too!

$\mathrm{AM}$ At the start of the year it can be just working on adding details to pictures. I love the idea about partners. You may even want to scaffold . . gradual release of responsibility. Complete the activity as a class, small groups, and then independently.

Despite those findings, qualitative analysis also revealed statements of dissonance. In responses to open-ended questionnaire items, and in transcripts from the digital discussions, some participants expressed specific concerns about ICT-based learning. Isolated remarks focused on the unavailability of technology in the school, the inappropriateness of global learning for young students, and how difficult it might be for participants to start the learning process for themselves and their students. Additionally, one participant called for balance between ICTbased learning and more traditional methods, "I think face-to-face communication is underrated in today's society, and I am NOT for replacing all human contact with computers, but I do see a place for global learning experiences in education." Although no negative theme or 
Table 7. Examples of Metacognitive Reflections Posted during Final ICT-based Learning Session

Example Reflections

Example 1 While in the breakout room, I asked the group for suggestions/activities that I could use to teach a particular student in my class the correct spelling of high frequency words. There were an abundant number of responses that I appreciated and have decided to use...

Example 2 There are infinite possibilities to extend learning this way as we share experiences and problem-solve together.

Example 3 I agree that the online classroom was a success. I feel that people are less afraid to share in this setting as opposed to having all eyes on them in the classroom. I enjoy learning from colleagues, and I got some great ideas that I will certainly take with me. I think also that a lot more is discussed and the conversation stays on task as opposed to how easy it is to get off task in the classroom.

pattern was evident, those isolated remarks did reflect beliefs or dispositions discrepant from those expressed by the majority of participants.

In summary, qualitative analysis identified two salient features of the participants' positive shift in disposition regarding ICT-based learning: 1) participants recognized the potential of ICT-based learning to motivate and engage learners, and 2) to facilitate the construction and sharing of knowledge and understanding. Contrasting those positive dispositions were isolated statements of concern and caution.

\section{Discussion}

Findings from this study yield answers to both of the research questions. Regarding the first question, graduate students and practicing teachers who participated in five global learning sessions across one semester did in fact demonstrate a statistically significant positive shift in disposition regarding the value of ICTbased learning. Regarding the second question, salient features of that positive shift were the participants' expressed beliefs that ICT-based learning had the potential to motivate and en- gage learners, and the potential to facilitate the construction and sharing of knowledge and understanding. Those recognitions are consistent with existing theory about the motivational potential of computer technologies (Barger \& Byrd, 2011; Beauvois, 1995; Warschauer, 1995, 1996), and with social constructivist theories about learning mediated by traditional discussions (Vygotsky, 1978) and computerbased global discussions (Leu, Kinzer, Coiro, \& Cammack, 2004; O'Brien \& Scharber, 2008; Tierney, 2009; Williamson, 2010). Hence, the findings from this study are not unexpected; the participants thought, behaved, and learned in ways predicted by, and consistent with accepted learning theories.

However, these findings add to our existing knowledge by validating what other researchers have proposed and by yielding important guidelines for how we might bridge the gap between theory and practice. Specifically, these findings support the suggestion (Cervetti, Damico, $\&$ Pearson, 2006) that engaging teachers and teacher candidates in learning not just about technology, but through technology might be an effective way to develop some positive dis- 
positions that correlate positively with classroom integration of computer-based learning. Additionally, they show that the much-desired dispositional shift can accompany a very brief and limited ICT-based learning experience embedded within existing syllabi and programs.

\section{Conclusions}

Knowing that positive dispositional shifts can accompany very limited learning experiences can be especially helpful and encouraging to teacher educators and professional developers who wonder if they can achieve the desired outcomes within the existing constraints of time and course content. Findings from this study suggest that extensive redesign of programs or reallocation of time for online learning may not be necessary; small changes can be effective. Embedding brief, limited ICT-based experiences into traditional courses and programs can help teachers and teacher candidates recognize the benefits of ICT-based learning, even as it enhances their knowledge and understanding of course content. Furthermore, it transforms our teaching and our students' learning. ICT moves us beyond the constraints of fixed, print text written only by established scholars and fosters the constructive processes that occur as learners participate in "a fuller and more open community of scholars interacting with one another" (Tierney, 2009, p.323).

Although findings from this study are encouraging, they must be interpreted carefully in light of limitations concerning the sample and data collection. The small sample was both idiosyncratic and convenient, not randomized. While six items on the questionnaires directly assessed the research questions, only two of them allowed for quantitative analysis. Although the wording of those items and response options is consistent with guidelines for developing affective instruments (Henk \& McKenna, 2004), validity and reliability stud- ies were not conducted. Furthermore, questionnaire-generated data, whether quantitative or qualitative, is self-reported rather than directly observed and triangulated. Also, despite the fact that participants' input did not impact their grades in the course, the possibility exists that participants responded positively because they believed the instructor wanted them to enjoy the course and its required components. Some participants may have inferred, while completing the late-semester questionnaire, the instructor's intent to compare early- and late-semester responses looking for positive change. Perhaps most important, enthusiastic and positive statements about ICT-based learning do not guarantee classroom application. Therefore, assessing the practical value of these positive findings calls for further research.

To address the limitations of this study, future research might expand the sample to include a more diverse population of participants who practice in various geographic and demographic settings and teach content areas other than literacy or language arts. Additionally, future studies might collect data reflecting not just participants' dispositions, but also their plans to integrate ICT-based learning into their classroom practice. Expanding the research focus even more, observational studies could examine the actual implementation of those plans. Case studies would enable researchers to identify challenges and barriers teachers encounter as they strive to implement ICT-based learning, as well as the strategies they use to meet the challenges and overcome barriers. Also important is to examine students' responses to teachers' implementation of ICT-based learning.

We trust that the findings from this study will encourage teacher educators and professional developers to implement similar ICTbased learning experiences into their practice. They will be confident that whatever limited steps they take will not only support teachers' 
understanding of course content, but also facilitate the development of positive dispositions.

\section{References}

Armstrong, S., \& Warlick, D. (2004). The new literacy. techLEARNING. Retrieved March 10, 2010, from http://www.techlearning. com/article/2806

Barger, A., \& Byrd, K. (2011). Motivation and computer-based instructional design. Journal of Cross-Disciplinary Perspectives in Education, 4(1), 1-9. Retrieved from http:// www.wmpeople.wm.edu/asset/index/ mxtsch/bargerbyrd.

Beauvois, M. H. (1995). E-talk: Attitudes and motivation in computer-assisted classroom discussion. Computers and the Humanities, 28, 177-190.

Cervetti, G., Damico, J., \& Pearson, P. D. (2006). Multiple literacies, new literacies, and teacher education. Theory into Practice, 45(4), 378-386.

Coiro, J., Knobel, M., Lankshear, C., \& Leu, D. J. (2008). Central issues in new literacies and new literacies research. In J. Coiro, M. Knobel, C. Lankshear, \& D. J. Leu, Eds.). Handbook of Research on New Literacies (pp. 1-19). New York: Lawrence Erlbaum Associates.

Ertmer, P. A. (2005). Teacher pedagogical beliefs: The final frontier in our quest for technology integration? Educational Technology Research and Development, 53(4), 25-39.

Florio-Ruane, S., \& Morrell, E. (2004). Discourse analysis: Conversation. In N. K. Duke \& M. H. Mallette (Eds.), Literacy Research Methodologies. New York: Guilford. Chapter 4, pp. 46-61.

Goldman, S. R., \& Wiley, J. (2004). Discourse analysis: Written text. In N. K. Duke \& M. H. Mallette (Eds.). Literacy Research
Methodologies. New York: Guilford. Chapter 5, pp. 62-91.

Guthrie, J. (2004). Teaching for literacy engagement. Journal of Literacy Research, 36(1), 1-29.

Henk, W. A., \& McKenna, M. C. (2004). Developing affective instrumentation for use in literacy research. In N. K. Duke \& M. H. Mallette, Eds. Literacy Research Methodologies. New York: Guilford.

Karchmer, R. A. (2001). The journey ahead: Thirteen teachers report how the Internet influences literacy and literacy instruction in their K-12 classrooms. Reading Research Quarterly, 36(4), 442-266.

Kay, R. H. (2006). Evaluating strategies used to incorporate technology into preservice education: A review of the literature. Journal of Research on Technology and Education, 38(4), 383-408.

Kuechler, M. (2008). Blackboard technology questionnaire. Retrieved December 9, 2008, from http://urban.hunter.cuny.edu

Leu D. J. (2001). Internet project: Preparing students for new literacies in a global village. Reading Teacher, 54(6), 568-572.

Leu, D. J., Jr., Kinzer, C. K., Coiro, J. L., \& Cammack, D. W. (2004). Toward a theory of new literacies emerging from the Internet and other information and communication technologies. In R. B. Ruddell, \& N. J. Unrau (Eds.), Theoretical Models and Processes of Reading, $5^{\text {th }}$ ed. (pp. 1570-1613). Newark, DE: International Reading Association.

MacArthur, C. A., \& Malouf, D. B. (1991). Teachers' beliefs, plans, and decisions about computer-based instruction. The Journal of Special Education, 25(5), 44-72. Marsh, J. (2008). Internet literacy influences: A review of Karchmer (2001). In J. Coiro, M. Knobel, C. Lankshear, \& D. Leu, (Eds.), Handbook of Research on New Literacies (pp. 1295-1306). New York: Lawrence Erlbaum Associates. 
O'Brien, D., \& Scharber, C. (2008). Digital literacies go to school: Potholes and possibilities. Journal of Adolescent \& Adult Literacy, 52(1), 66-68.

Richardson, W. (2010). Blogs, Wikis, Podcasts, and Other Powerful Web Tools for Classrooms. Thousand Oaks, CA: Corwin.

Rother, C. (2004). Evaluating technology's role in the classroom: Second annual "Teachers Talk Tech" survey examines the long-term impact of technology on learning. Technological Horizons in Education, 32(3), 43-49.

Tan, L., \& Guo, L. (2009/2010). From print to critical multimedia literacy: One teacher's foray into new literacies practices. Journal of Adolescent \& Adult Literacy, 53(4), 315-324.

Tierney, R. J. (2009). Shaping new literacies research: Extrapolations from a review of the Handbook of Research on New Literacies. Reading Research Quarterly, 44(3), 322-339.

Vannatta, R. A., \& Fordham, N. (2004). Teacher dispositions as predictors of classroom technology use. Journal of Research on Technology in Education, 36(3), 253-271.

Vygotsky, L. S. (1978). Mind in society: The development of higher psychological processes. Cambridge, MA: MIT Press.

Warschauer, M. (1995). Comparing face-toface and electronic discussion in the second language classroom. CALICO Journal, 13(2), 7-26.

--- (1996). Motivational aspects of using computers for writing and communication. In M. Warschauer (Ed.) Telecollaboration in Foreign Language Learning. Honolulu, HI: University of Hawai'i Press. pp. 29-46.

Williams, J. B. (2011). Pedagogy 2.0: ICTs and disruptive innovation. Retrieved from http://authenticlearning.wordpress. $\mathrm{com} /$ ? $\mathrm{s}=$ disruptive + innovation

--- (2011). Education's Internet moment is now. [Web log comment] Retrieved from http:// authenticlearning.wordpress.com

\section{Acknowledgements}

The authors are grateful to Lisa M. Anderson and the JETDE reviewers for their input on earlier stages of this work, and to Jamie Moyer for her assistance in creating tables and figures.

\section{Contact the Authors}

Carol A. Smith, Ed.D.

West Chester University of Pennsylvania

Email: Csmith3@wcupa.edu

Cynthia A. Moyer, MAT.

J. Mason Tomlin School of Mantua

Email: cmoyer@mantuaschools.com

Heather R. Schugar, Ph.D.

West Chester University of Pennsylvania Email: hschugar@wcupa.edu 